УДК 621.039.73

Doi: https://doi.org/10.32918/nrs.2019.1(81).09

\section{Сучасні методи}

радіохімічної переробки відпрацьованого ядерного

\section{палива}

Мальцева Т. В.

Державне підприємство «Державний науково-технічний центр з ядерної та радіаційної безпеки», м. Київ, Україна ORCID: https://orcid.org/0000-0002-7865-1378

Шишута А.М.

Державне підприємство «Державний науково-технічний центр з ядерної та радіаційної безпеки», м. Київ, Україна ORCID: https://orcid.org/0000-0002-8321-3153

Лукашин С. О.

Державне підприємство «Державний науково-технічний центр з ядерної та радіаційної безпеки», м. Київ, Україна ORCID: https://orcid.org/0000-0002-6047-0165

Статтю присвячено історії розвитку та сучасному стану технологіч них та наукових досягнень у галузі радіохімічної переробки відпрацьованого ядерного палива енергетичних реакторів з водним охолодженням. Відносно відпрацьованого ядерного палива (ВЯП) енергетичних реакторів атомних електростанцій (AEC) довгострокова енергетична безпека передбачає прийняття варіанту його радіохімічного очищення кондиціонування та рециркуляції. Переробка ВЯП необхідна для реалізації замкнутого паливного циклу та повторного використання продуктів регенерації у якості палива енергетичних реакторів. Основою сучасних технологічних схем для переробки відпрацьованого ядерного палива є процес «Purex», розроблений з 60-х років в США. Класичний підхід до використання нуклідів урану та плутонію, що містяться у відпрацьованому ядерному паливі, полягає у відокремленні їх від продуктів поділу, збагачення відновленого урану та використання плутонію для виробництва змішаного оксидного палива (ЗМОКС) зі збідненим ураном. Сучасні переробні заводи здатні працювати з паливом при подальшому збільшенні його основних характеристик без суттєвих змін у вихідному проекті. Для того, щоб закрити паливний цикл, необхідно додати наступні технологічні етапи: (1) видалення високоактивних і довгоживучих компонентів і мінорних актинідів; (2) повернення актинідів до технологічного циклу; (3) безпечна утилізація невикористовуваних компонентів. Кожен із цих напрямків є предметом сучасних досліджень. Розроблено кілька нових перспективних багато-стадійних гідрометалургійних процесів на основі спільного вилучення тривалентних лантанідів та мінорних актинідів з їх подальшим поділом. Розроблено ряд перспективних матеріалів, які є потенційними матрицями для іммобілізації високоактивних компонентів ВЯП. Для поліпшення сумісності обробки палива з середовищем розробляються неводні технології, наприклад, пірохімічні способи переробки різних видів високоактивних видів палива на основі металів, оксидів, карбідів або нітридів. Важливим науково-технічним дослідницьким завданням є трансмутація актинідів. Результати міжнародних масштабних експериментів з розподілу і трансмутації палива з різними мінорними актинідами та довгоживучими продуктами поділу підтверджують реальну можливість та доцільність закриття ядерного паливного циклу.

Ключові слова: відпрацьоване паливо, переробка, уран, плутоній, актиніди, трансмутація.

(C) Мальцева Т. В., Шишута А.М. , Лукашин С. О. 2019
$\mathrm{C}$ тосовно відпрацьованого ядерного палива енергетичних реакторів АЕС довгострокова енергетична безпека передбачає прийняття варіанту його радіохімічної переробки, кондиціонування i рециркуляції. Переробка ВЯП енергетичних реакторів потрібна для реалізації закритого паливного циклу і повторного використання продуктів регенерації в якості енергетичного реакторного палива. Уран може бути використаний в виробництві палива для реакторів на теплових нейтронах (РТН), у вигляді палива в суміші 3 оксидом плутонію (змішане оксидне паливо (ЗМОКС)), а також, для спалювання у реакторах на швидких нейтронах (РШН), так само, як і мінорні актиніди і деякі з довгоживучих продуктів поділу. В завдання переробки з метою регенерації палива входять: мінімізація радіаційної небезпеки ВЯП, виділення з ВЯП корисних речовин і їх подальше використання, безпечна утилізація не використовуваних компонентів.

В Україні прийнято рішення про зберігання відпрацьованого палива протягом декількох десятків років (так зване «проміжне зберігання»). Здійснюється будівництво спеціальних проміжних «сухих» сховищ для зберігання ВЯП без його хімічного розчинення і переводу в рідкий стан. Для ВЯП Запорізької АЕС, де працює 6 реакторів ВВЕР1000, створено пристанційне сховище контейнерного типу. ВЯП Рівненської, Хмельницької та Южно-Української АЕС розміщуватиметься у централізованому сховищі для цих трьох станцій. Можливість зберігання ВЯП на своїй території забезпечить тривалу стабільну роботу українських атомних станцій і дозволить уникнути ризиків залежності від монопольного іноземного постачальника послуг з його зберігання і переробки. Крім того, прийняте рішення дозволяє отримати запас часу для остаточного вибору відносно ВЯП за альтернативою «захоронювати або переробляти?» з урахуванням новітніх і майбутніх можливостей науки і техніки.

При радіохімічній переробці, або репроцесінгу, відпрацьоване паливо повинно бути розчинено, уран і плутоній - вилучені окремими стадіями хімічного розділення і регенерації. Виділення деяких високоактивних актинідів із залученням до паливного циклу, або окремим захороненням, дозволить суттєво знизити радіаційну небезпеку відпрацьованого палива. Метою статті $€$ огляд технологій і наукових розробок щодо радіохімічної переробки ВЯП енергетичних легководних реакторів. Розглянуто технологічні складові паливного циклу, склад палива, розвиток радіохімічної переробки і сучасний стан наукових і технічних розробок щодо переробки ВЯП і вибіркового вилучення і трансмутації мінорних актинідів і інших компонентів.

\section{Технологічні складові ядерного паливного циклу}

Ядерний паливний технологічний цикл (ЯПЦ) це сукупність способів видобутку урану, виробництва палива для ядерних реакторів, його використання та утилізація. ЯПЦ РТН з поверненням урану включає в себе наступні стадії: видобуток, очищення, хімічна конверсія і збагачення урану, виготовляння палива, (можливо) «сухе» проміжне зберігання, розчинення в кислоті, хімічне вилучення окремих компонентів, конверсія виділеного урану і його повернення в паливний цикл. На рис. 1 представлені відповідні виробництва сучасного технологічного ядерного циклу. Паливний цикл може бути відкритим або закритим в залежності від поводження з ВЯП. 


\section{Ядерний паливний цикл}

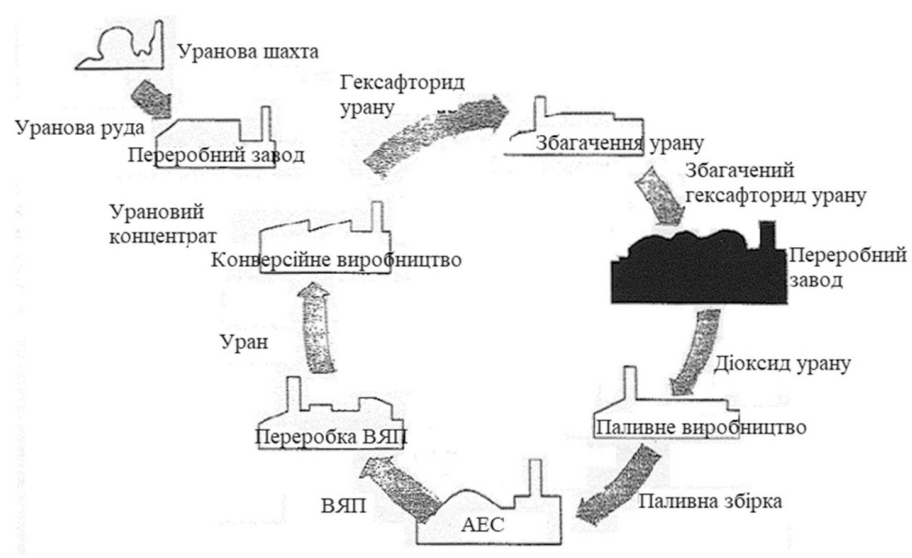

Рис. 1. Технологічні складові паливного циклу РТН

При відкритому паливному циклі (ВЯПЦ) уран збагачують і використовують для виробництва палива, а ВЯП відправляють на захоронення як радіоактивні відходи. Перевага ВЯПЦ полягає у виключенні трудомісткого етапу переробки опроміненого палива. Проте при використанні у відкритому циклі в легководних реакторах відомі ресурси урану, за оцінками, закінчуються до завершення цього століття. Основна перевага закритого ядерного паливного циклу (ЗЯПЦ) - можливість використання енергії не тільки $235 \mathrm{U}$, але й плутонію, спільно з високоактивними актинідами, що утворюються при опроміненні $238 \mathrm{U}$.

Шоб «закрити» паливний цикл, необхідно додати наступні технологічні стадії: (1) вилучення високоактивних довгоживучих продуктів поділу і актинідів, а також, цезію, стронцію; (2) повернення актинідів в технологічний цикл; (3) безпечна утилізація невикористаних компонентів (скловування, захоронення).

Класичний підхід до використання нуклідів урану і плутонію, що містяться в ВЯП, полягає в їх виділенні при переробці, повторному дозбагаченню регенерованого урану і використанні плутонію для виготовлення ЗМОКСпалива зі збідненим ураном. ЗМОКС-паливо може застосовуватися як додаткове паливо для найбільш поширеного типу ядерних реакторів, а саме, легководних РТН. Однак більш ефективне використання ЗМОКС-палива - його спалювання в РШН. У $70-\mathrm{x}$ роках XX століття інтерес до РШН був дуже високий, однак потім в США, Німеччині, Великобританії та Франції програми розвитку РШН були припинені через наявність значних запасів природного урану, що використовується в РТН. Однак сьогодні увагу до РШН знову зросла в зв'язку з обмеженістю ресурсів природного урану.

Конкурентоспроможність АЕС 3 РШН буде обумовлена, головним чином, витратами на виготовлення ЗМОКС-палива, виробництво електроенергії і переробку ВЯП, а також витратами на транспортування і зберігання ВЯП. При цьому треба мати на увазі, що головним конкурентом ЗЯПЦ РШН є ВЯПЦ РТН, який вже має розвинену інфраструктуру по всьому паливному циклу. Проте, і вона вимагає подальшого розвитку і вирішення ряду завдань, перш за все, більш ефективного поводження з ВЯП.

\section{Склад відпрацьованого палива}

Паливо вивантажують 3 реактора у вигляді збірок тепловиділяючих елементів (твелів), які можуть мати температуру до $300^{\circ} \mathrm{C}$. Тому їх занурюють у басейн витримки при АЕС для охолодження і поглинання радіоактивного випромінювання. Термін витримки залежить від концентрації і складу продуктів розпаду і синтезу, а також, від залишкового тепловиділення. Коли активність зменшується до норм, що визначають безпеку транспортування палива, ВЯП може бути переміщене в довгострокове сховище.

Уран у тепловиділяючому елементі має форму таблеток з оксиду урану. При розпаді урану утворюються нестабільні ізотопи інших хімічних елементів, в тому числі газоподібних. Вимоги безпеки регламентують герметичність твелів, відповідно, всередині твелу залишаються продукти розпаду урану. Відпрацьоване паливо на 95,6 \% складається з урану, якого в ядерному реакторі витрачається всього 3-4\%. Це значні кількості урану-238, невеликі кількості урану-235. Склад інших 4,4 \% є наступним: 2,9\% - стабільні продукти випромінювання, 0,9 \% плутонію, 0,3 \% цезій і стронцій, 0,1\% - високоактивні мінорні актиніди (МА) з періодом напіврозпаду $10^{3}-10^{6}$ років (Am, Cm, та ін.), $0,1 \%$ - довгоживучі актиніди 3 максимальною радіотоксичністю I і Тc, 0,1\% - довгоживучі інші продукти поділу [1]. Активність мінорних актинідів може досягати 9,6 $10^{14}$ Бк на 1 кг ВЯП. Від радіонуклідів цезію і стронцію йде максимальне тепловиділення, на зменшення якого до нуля потрібно 300 років. Серед радіоактивних продуктів поділу міститься велика кількість цінних радіонуклідів, які можна використовувати в області малої ядерної енергетики (радіоізотопні джерела тепла для термогенераторів електроенергіi), а також для виготовлення джерел іонізуючого випромінювання. Застосування знаходять трансуранові елементи, що створюються в результаті побічних реакцій ядер урану з нейтронами. Радіохімічна технологія переробки ВЯП повинна забезпечувати вилучення всіх нуклідів, що є корисними з практичної точки зору або представляють науковий інтерес.

\section{Переробка відпрацьованого палива в розчинах (історія)}

Перша стадія радіохімічного виробництва включає підготовку палива, тобто звільнення його від конструкційних деталей зборок і руйнування захисних оболонок твелів. Після цього паливна композиція стає доступною для дії хімічних реагентів. Наступна стадія пов'язана зі зміною агрегатного стану ядерного палива і його перетворенням відповідно до фази, з якої буде проводитися хімічна обробка: в розчин, в розплав, або в газоподібній стан. Найбільш прості методи переробки відпрацьованого палива було розроблено для хімічних процесів у розчинах.

Першим розробленим технологічним процесом регенерації енергетичного палива було виділення з ВЯП «збройового» плутонію 239Pu вісмут-фосфатним осадженням [2].

Вісмут-фосфатне осадження. В результаті Манхеттен ського проекту в 1942 році вісмут-фосфатним осадження отримали перші мікрограми 239Pu. Уже в 1944 р. кількість отриманого плутонію складала 1 кілограм, тобто фактор збільшення маси продукту склав $10^{9}$. Плутоній осаджувався у вигляді $\mathrm{Pu}_{3}\left(\mathrm{PO}_{4}\right)_{4} 3$ подальшою переробкою в азотній кислоті та окисленням плутонію до $\mathrm{Pu}$ (VI) 
i переосадженням фосфатом вісмуту $\mathrm{BiPO}_{4}$ для очищення плутонію від продуктів радіоактивного розпаду. До переваг вісмут-фосфатного осадження можна віднести $95 \%$ відновлення плутонію та високий фактор очистки $\left(10^{7}\right)$. Недоліками процесу є велика кількість високоактивних відходів і неможливість повернення в технологічний паливний цикл урану 235U. Пізніше процеси вилучення 3 розчинів були доповнені паралельним розділенням плутонію та урану, і процес був зосереджений на регенерації та поверненні цих компонентів, а також на переробці відходів.

REDOX-проиес. Безперервний процес рідинної екстракції, що повертає в технологічний цикл як плутоній, так і уран, використовувався в Айдахо для повернення урану-235. Для очищення уранових концентратів використовували реагент гексон. 3 відпрацьованого палива вибірково вилучали нітрати урану і плутонію. Плутоній для кращого вилучення окислювали до 6-валентного. Уран і плутоній екстрагували у суміші, і потім плутоній відновлювали сульфатом заліза до 3-валентного стану. Недоліками методу є велика кількість сольових реагентів, яка збільшує обсяг відходів; а також, вогненебезпечність і летючість гексону.

BUTEX-nроиес. У розробленому в кінці 1940-х рр. британськими вченими (лабораторія Chalk River) BUTEXпроцесі використовували інший розчинник (дібутілкарбітол), з більш низьким тиском пари, ніж гексон. Метод використовували на заводі Windscale у Великобританії до 1976 року.

\section{PUREX-процес для регенерації плутонію і урану}

В основі всіх сучасних технологічних схем переробки ВЯП лежать екстракційні процеси. Найчастіше це розроблений з 60-х в США так званий $P U R E X$-процес (від англ. $P u, U$ Recovery EXtraction) [3]. Він полягає в відновлювальній реекстракції плутонію з спільного екстракту з ураном і продуктами ділення. У якості екстрагенту використовують трибутилфосфат (TBP) у вуглеводневому розчиннику. У процесі переробки в першу чергу проводиться виділення урану і плутонію і очищення їх від радіоактивних продуктів поділу, в тому числі від нейтронопоглинаючих нуклідів (нейтронних отрут), які при повторному використанні випромінюючих матеріалів можуть перешкоджати розвитку в реакторі ланцюгової ядерної реакції. В даний час це найбільш розвинений і широко використовуваний в галузі процес. Конкретні схеми переробки відрізняються набором реагентів, послідовністю окремих технологічних стадій, апаратурним оформленням. Технологія PUREX надійна як в лабораторному, так і в промисловому виконанні. 3 моменту відкриття першого заводу PUREX на річці Саванна в 1954 році, цей процес було застосовано у різних варіантах технологічних схем і все ще використовується для комерційної переробки ВЯП.

Завдяки безперервному удосконаленню технологічних операцій сучасні переробні заводи здатні приймати паливо з характеристиками, відмінними від тих, що були спочатку. Типовий завод для переробки палива, отриманого з легководних реакторів, проектувався для ВЯП 3 початковим збагаченням $3 \%$ урану- 235 , вигоранням 30 ГВт/т і строком охолодження 3 роки. У 2005 р. паливо у середньому мало початкове збагачення $~ 3,7 \%$ урану-235, при вигоранні, яке могло досягати 45 ГВт/т, і вимагало 4-річного періоду охолодження. Досвід роботи більшості переробних підприємств показав, що технічно вони здатні переробляти паливо з подальшим підвищенням вказаних характеристик без суттєвих змін у проекті [4].

За останні десятиріччя поєднання навчання з досвідом експлуатації та постійним удосконаленням і модифікаціями вихідного проекту призвело до зменшення середньорічного опромінення працівників заводів з переробки ВЯП 3 понад 10 мЗв до 1,5 мЗв на людину. Радіаційне опромінення населення також зменшилося, значною мірою у відповідності до зменшення кількості радіоактивних викидів заводів з переробки ВЯП [2].

\section{Сучасні модифікації PUREX-процесу [5]}

В подальшому удосконаленні технології найбільш важливим стає екологічний аспект.

$U R E X$-процес. При використанні палива з енергетичних реакторів після досить тривалої кампанії витягнутий плутоній зазвичай містить занадто багату кількість (не менш ніж 30\%) ізотопу $\mathrm{Pu}-240$, щоб вважатися «збройовим» плутонієм. Їзотоп $\mathrm{Pu}-240 €$ забруднювачем, через що таке паливо не може бути використане для виготовлення надійних і передбачуваних ядерних зарядів [9]. Тем не менш, $U R E X$ - процес, який є модифікацією PUREX- процесу, був розроблений для того, щоб запобігти окремому видобутку і можливому розповсюдженню плутонію. Це можна зробити шляхом додавання до плутонію відновника перед першим етапом екстракції металу. У процесі $U R E X$ регенеруються 99,9\% урану та $>95 \%$ технецію, у процесі вони відділяються один від одного, а також, від інших продуктів поділу та актинідів. Ключовим є додавання ацетогідроксамінової кислоти ( $A H A)$ до секцій екстракції та осадження. Додавання $A H A$ значно зменшує витягування плутонію та нептунію, ніж стадія екстракції плутонію процесу PUREX. Цим кроком зменшується вірогідність розповсюдження ізотопів плутонію. Запропоновані та розроблені зміни до процесу $P U R E X$ залишають невелику частину урану з плутонієм, виробляючи змішаний продукт для ЗМОКС-палива.

$T R U E X$-процес. Додаванням другого екстрагенту, октил(феніл)-N,N-дибутилкарбамоїлметилфосфіноксиду $(C M P O)$ в поєднанні 3 трибутилфосфатом, процес PUREX можна перетворити в процес TRUEX (TRansUranic EXtraction), якій було винайдено в США, в Національній лабораторії Argonne. Процес призначено для видалення трансуранових металів $(\mathrm{Am} / \mathrm{Cm})$ з високоактивних відходів. Їдея полягає в тому, щоб суттєво зменшити альфа-активність відходів.

$D I A M E X$-процес. В якості альтернативи TRUEX був розроблений процес екстракції з використанням малондиаміда. Перевага процесу DIAMEX (DIAMide EXtraction) полягає в тому, шо при його здійсненні уникають створення органічних відходів, які містять елементи, відмінні від вуглецю, водню, азоту і кисню. Такі органічні відходи можуть спалюватися без виділення кислотних газів, які сприяють появі кислотних дощів. Процес DIAMEX розробляється в Європі французькою компанією $C E A$ (Commissariat a l'ǔnergie atomique et aux ŭnergies alternatives). Процес розроблено достатньо для побудови сучасного промислового заводу.

SANEX-процес. (Selectine ActiNide EXtraction). В рамках поводження з мінорними актинідами було запропоновано видалити з рафінаду PUREX лантаніди і тривалентні 
мінорні актиніди за допомогою процесу, такого як DIAMEX, або TRUEX. Щоб здійснити можливість використовувати мінорних актинідів, наприклад, америцію, в промислових джерелах енергії, або повторно в якості палива, необхідно видалити лантаніди. Лантаніди мають великі значення перерізу нейтронів і, отже, будуть отруювати нейтронну ядерну реакцію. На сьогоднішній день система вилучення для процесу $S A N E X$ не визначена, але в даний час кілька різних дослідницьких груп працюють над процесом. Наприклад, французька $C E A$ працює над процесом на основі біс-триазінілпіридина (BTP). Їнші системи, такі як дитіофосфінові кислоти, розробляються деякими іншими дослідницькими групами.

UNEX-процес. Процес UNiversal EXtraction був розроблений в Росії і Чехії; він призначений для повного видалення найбільш радіотоксичних ізотопів (Sr, Cs і мінорних актинідів) з рафінаду, що залишається після вилучення з ВЯП урану і плутонію. Хімія процесу заснована на взаємодії цезію та стронцію з поліетиленгліколем і аніонами кобальтового карборану (відомого як хлорований кобальтдикарболід). Актиніди екстрагують СМРО, застосовують полярний ароматичний розчинник, такий як нітробензол. Також були запропоновані інші розчинники, такі як метанітробензотрифторид і фенілтрифторметилсульфон.

Великі радіохімічні виробництва діють в Англії (завод Селлафілд), у Франції (завод Cogema), Японії (Rokkasho), Росії (Маяк). Планується запуск в Китаї (Lanzhou, 2020).

\section{Сучасний стан наукових і технічних розробок щодо переробки ВяП і вибіркового вилучення мінорних актиноїдів}

Для підвищення сумісності переробки ВЯП з екологією розробляються неводні технологічні процеси, в основі яких лежать відмінності летючості компонентів ВЯП (дистиляційні процеси), фракційна кристалізація з розплавів, екстракція розплавами солей, сорбція при високій температурі на неорганічних сорбентах, зонна плавка. Головною перевагою неводних процесів є компактність, відсутність як великих розведень, так і створення великої кількості рідких радіоактивних відходів. Відходи займають значно менший об’єм і знаходяться у твердому стані. Ці «сухі» процеси науково-дослідні центри розробляли в початковий період розвитку ядерної енергії як елемент паливного циклу РШН, але затримка комерціалізації РШН стала головною причиною того, що науково-дослідні роботи не були в свій час доведені до промислових технологій. 3 виникненням зацікавленості в технічній можливості трансмутації актинідів, науково-дослідними центрами були переглянути деякі пірохімічні методи обробки ВяП. Пірохімічна обробка в розплаві є перспективною альтернативою водній переробці відпрацьованого палива, особливо для РШН 3 металевим типом палива [10]. Розробляються пірохімічні методи для переробки різних типів високоактивного палива на основі металів, оксидів, карбідів, або нітридів. Розроблено перспективні пірометалургійні процеси, наприклад, пряме розчинення палива легководних реакторів контактним електролізом (British Nuclear Fuels Ltd (BNFL)).

Останнім часом в Росії досліджується пропозиція Радієвого інституту по використанню в реакторах BBEP-1000 REMIX-палива (Regenerated Mixture of $U_{-}, P_{u-}$ oxides), регенерованого безпосередньо з нерозділеної суміші урану та плутонію, які виділяються при переробці
ВЯП після підживлення природним збагаченим ураном. Запропонована технологія планує повторне використання не тільки плутонію, шо міститься в ВЯП, а й залишкової кількості 235U. Модернізація існуючої інфраструктури РТН з використанням $R E M I X$-палива і подальшим створенням власної інфраструктури замкнутого ЯПЦ РШН $\epsilon$ привабливим варіантом, який дозволяє у майбутньому здійснити ефективний запуск ЗЯПЦ для РШН. Як показали розрахунки, використання $R E M I X$-палива $(1,0-1,5 \%$ $\mathrm{Pu}+2,5 \% 235 \mathrm{U})$ дозволяє багаторазово рециклювати всю кількість урану і плутонію, шо виділяється з ВЯП РТН, при $100 \%$-ному завантаженні таким паливом активної зони реактора ВВЕР-1000. Навіть при п'яти рециклах склад нуклідів урану і плутонію змінюється несуттєво. Використання $R E M I X$-палива, в порівнянні з відкритим ЯПЦ, дозволяє знизити споживання природного урану в РТН на $20 \%$ при кожному рециклі. Цей показчик удвічі більше, ніж при використанні $M O X$-палива.

Важливим науковим і технологічним завданням $є$ вилучення і трансмутація актинідів. Під час експлуатації в реакторі в ядерному паливі накопичуються актиніди: ізотопи плутонію і так звані мінорні актиніди (МА) - paдіоактивні елементи америцій, кюрій, нептуній, самарій. Всі вони альфа-активні і відрізняються високою радіоактивністю. Період напіврозпаду високоактивних актинідів становить $10^{4}-10^{6}$ років (Таблиця).

Таблиця. Період напіврозпаду $T_{1 / 2}$ деяких актинідів

\begin{tabular}{|c|c|c|c|}
\hline Актинід & $T_{\mathbf{1} / \mathbf{2}}$, років & Актинід & $T_{\mathbf{1} / \mathbf{2}}$, років \\
\hline $239 \mathrm{Pu}$ & $2,4110^{4}$ & $243 \mathrm{Am}$ & $7,3810^{3}$ \\
\hline $240 \mathrm{Pu}$ & $6,5610^{3}$ & $245 \mathrm{Cm}$ & $8,510^{3}$ \\
\hline $242 \mathrm{Pu}$ & $3,7310^{5}$ & $237 \mathrm{~Np}$ & $2,1610^{6}$ \\
\hline
\end{tabular}

Якщо немає можливості їх виділення та практичного застосування, актиніди і суміші, що їх містять, необхідно зберігати десятки тисяч років. Проте, в разі вилучення цих елементів 3 опроміненого ядерного палива, актиніди можуть бути використані повторно в якості палива. Вилучення цих елементів з відпрацьованого палива дозволить зберігати ВЯП, чекаючи природної дезактивації, набагато менший час. Зменшення часу зберігання складає $3 \sim 100000$ років до $\sim 300$ років (Рис. 2) [1]. Відходи ядерної енергетики, що залишаться після їх вилучення, будуть відрізнятися набагато меншим рівнем радіоактивності.

Перетворення ізотопів плутонію і довгоживучих актинідів в короткоживучі радіонукліди або навіть в стабільні ізотопи за допомогою опромінення в реакторі (трансмутаціï) в теорії може вирішити ряд проблем. Трансмутація актинідів до продуктів поділу принаймні суттєво зменшить довгострокову радіотоксичність палива і екологічне навантаження на навколишнє середовище. Але для здійснення подібного процесу необхідно розробити технології вилучення $з$ відпрацьованого ядерного палива та високоактивних відходів саме актинідів. На даний момент розробленими є вищевказані модифікації основної технології $P U R E X$, a саме, DIAMEX-SANEX-процес (видалення з рафінаду $P U R E X$ лантанідів і тривалентних МА) і $U N E X$-процес (видалення радіоізотопів $\mathrm{Sr}$, Cs і МА) у Франції, TALSPEAK у Америці, TOGDA у Японії [5], а також, гідрометалургійну регенерацію актинідів (GANEX-процес) [6]. 


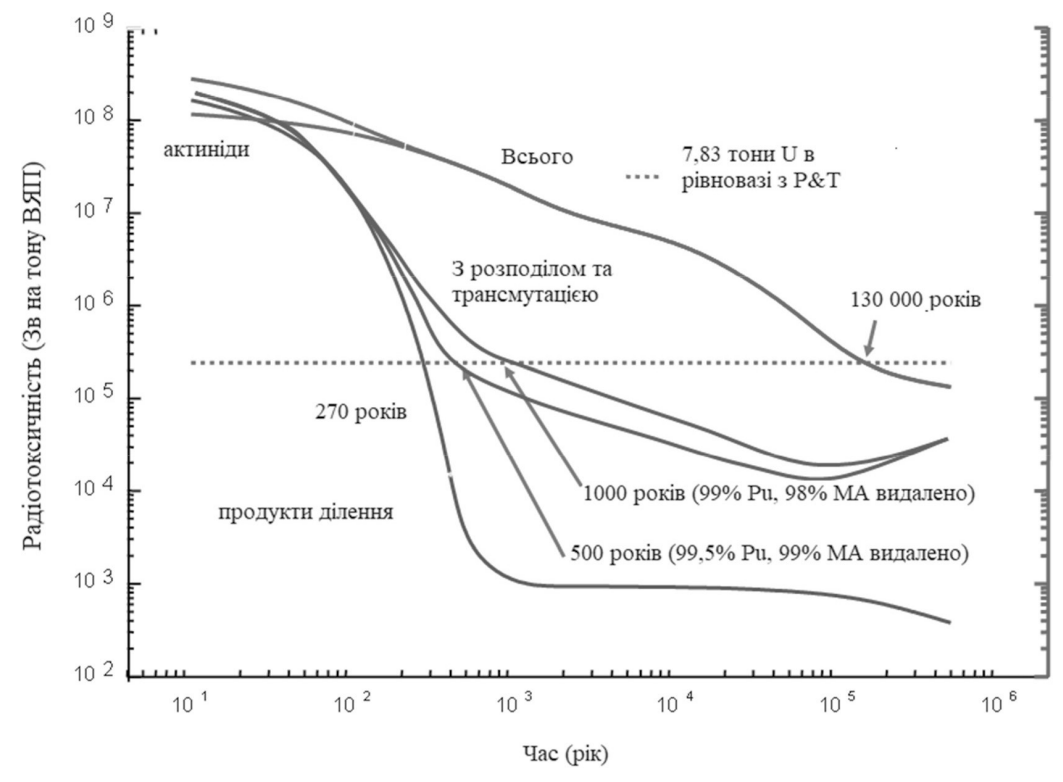

Рис. 2. Радіотоксичність відпрацьованого палива в залежності від часу зберігання (у роках): MA - мінорні актиніди (minor actinides), $\mathrm{Pu}$ - плутоній, $\mathrm{P} \& \mathrm{~T}$ - розподіл і трансмутація (Partitioning and Transmutation). Наведені дані базуються на ICR P72
Розроблено кілька перспективних багатоциклових гідрометалургійних процесів, заснованих на спільній екстракції тривалентних лантанідів і МА 3 їх подальшим розділенням [7-11]. 3 точки зору (не)розповсюдження високоактивних матеріалів, що діляться, привабливим є єдина екстракційна стадія для всіх актинідів, пошук відповідної екстракційної системи є також важливим науковим завданням. В дослідницькі завдання входять пошук нових екстрагентів, здатних відокремлювати мінорні актиніди від лантаноїдів, ведуться роботи у цьому напрямку [12, 13].

Як потенційні матеріали для іммобілізації радіоактивних відходів високого рівня у даний момент досліджують кристалічні керамічні матриці, зокрема, фосфати лантаноїду $\left(\mathrm{LnPO}_{4}\right)$, спеціально для іммобілізації МА і плутонію [20]. Проводяться декілька міжнародних великомасштабних експериментів з поділу та трансмутації МА. В експериментах SUPERFACT (склад палива (U, Pu, MA) $\mathrm{O}_{2}$ ) та METHAFIX (U, Pu, $\mathrm{Zr}, \mathrm{Np}, \mathrm{Am}, \mathrm{Cm})$ паливо, яке містило різні МА і довгоживучі продукти поділу, було виготовлено, охарактеризовано, опромінено швидкими нейтронами, проаналізовані результати, та здійснена його регенерація або шляхом водного репроцесінгу, або шляхом піропереробки $[1,14]$. Отримані показники трансмутації складають у середньому $30 \%$, але була досягнена і більша величина, $45 \%$ (ступінь трансмутації залежить від вигорання палива). Результати цих експериментів підтверджують реальну можливість і доцільність закриття ядерно-паливного циклу.

\section{Висновки}

1. Переробка відпрацьованого палива енергетичних реакторів на теплових нейтронах потрібна для реалізації закритого паливного циклу і повторного використання продуктів регенерації в якості енергетичного реакторного палива, вона є доцільною альтернативою захороненню.

2. Регенеровані основні компоненти палива - уран і плутоній, а також, актиніди і довгоживучі продукти поділу, можуть бути застосовані у виготовленні змішаного оксидного або металевого палива для реакторів як на швидких, так і на теплових нейронах.

3. Трансмутація високоактивних компонентів відпрацьованого палива, а саме, мінорних актинідів і довгоживучих продуктів поділу, здатна суттєво зменшити екологічне навантаження на навколишнє середовище.

4. Сучасний стан науково-технічних розробок щодо переробки відпрацьованого ядерного палива підтверджують реальну можливість і доцільність закриття ядерно-паливного циклу, яке передбачається сучасною стратегією довгострокової енергетичної безпеки.

\section{Список використаної літератури}

1. Fanghanel Th. Closing the Nuclear fuel Cycle for Future Sustainable Nuclear Energy. - Abstracts of $9^{\text {th }}$ International Conference on Nuclear and Radiochemistry - NRC9. 2017. P. 49.

2. International Atomic Energy Agency. Status and Trends in Spent Fuel Reprocessing. IAEA-TECDOC-1467. Vienna, 2005.

3. Wolf J.-M. History of the Eurochemic Company. OECD, Paris. 1996.

4. Kiuchi K, et al. Technological problems and counter-measures on equipment materials for reprocessing of high-burnup fuels. IAEA-TECDOC-1299. Technical and economic limits to burnup (2002).

5. International Atomic Energy Agency. Spent Fuel Reprocessing Options. IAEA-TECDOC-1587. Vienna, 2008.

6 . Adnet J., et al. The development of new hydrometallurgical processes for actinides recovery: The GANEX process. Global 2005 (9-13 Oct., Tsukuba).

7. Ansari S. A., Pathak P., Mohapatra P. K., Manchanda V. K. Chem. Rev. 2012. Vol. 112. P. 1751-1772.

8. Serrano-Purroy D., Baron P., Christiansen B., Glatz J. P., Madic C., Malmbeck R., Modolo G. Separation and Purification Technology. 2005. Vol. 45. P. 157-162.

9. Modolo G., Wilden A., Geist A., Magnusson D., Malmbeck R. Radiochim. Acta. 2012. Vol. 100. P. 715-725.

10. Ossola A., Macerata E., Tinonin D.A., Faroldi F., Giola M., Mariani M., Casnati A. Radiat. Phys. Chem. 2015.

11. Macerata E., Ossola A., Giola M., Faroldi F., Tinonin D. A. Actinide-lanthatide co-extraction by rigidified diglycolamides. Solvent Extraction and Ion Exchange. Vol. 36, Iss 1 (https://doi.org/10.1080/07 366299.2017.1415670)

12. Lavrov G., Ustynyuk N., Gloriozov I., Ustynyuk Yu., Alyapyshev M., Tkachenko L., and Babain V. A novel selective $\mathrm{N}$-heterocyclic ligands for extraction separation of actinides and lanthanides. Abstracts of $9^{\text {th }}$ International Conference on Nuclear and Radiochemistry. NRC9. 2017. P. 71.

13. N. Huittinen, A. C. Scheinost, A. Wilden, Y.Arinicheva $\mathrm{Cm}^{3+}$ incorporation in $\mathrm{La}_{1-\mathrm{x}} \mathrm{Gd}_{\mathrm{x}} \mathrm{PO}_{4}$ monazites: a TRLFS and XAFS study. Abstracts of $9^{\text {th }}$ International Conference on Nuclear and Radiochemistry. NRC9. 2017. P. 140. 
14. H. Ohta, T. Ogataa, S. Van Winckelb, D. Papaioannoub and V. V. Rondinella. Evaluation of Minor Actinide Transmutation Performance in Fast Reactor Metal Fuel Irradiated up to $\sim 6.0$ at.\% Burnup.. Nuclear Science $N E A / N S C / R$. 2015. P. 2.

\section{References}

1. Fanghanel Th. (2017). Closing the Nuclear fuel Cycle for Future Sustainable Nuclear Energy. Abstracts of $9^{\text {th }}$ International Conference on Nuclear and Radiochemistry. NRC9. P. 49.

2. International Atomic Energy Agency. Status and Trends in Spent Fuel Reprocessing, IAEA-TECDOC-1467, Vienna, 2005.

3. Wolf, J.-M. (1996). History of the Eurochemic Company. OECD, Paris, 1996.

4. Kiuchi, K., et al. (2002). Technological problems and countermeasures on equipment materials for reprocessing of high-burnup fuels. IAEA-TECDOC-1299. Technical and economic limits to burnup, 2002.

5. International Atomic Energy Agency. Spent Fuel Reprocessing Options, IAEA-TECDOC-1587, Vienna, 2008.

6. Adnet, J., et al. (2005). The development of new hydrometallurgical processes for actinides recovery: The GANEX process. Global 2005, Tsukuba.

7. Ansari S. A., Pathak P., Mohapatra P. K., Manchanda V. K. (2012) Chem. Rev. 112, 1751-1772.

8. Serrano-Purroy D., Baron P., Christiansen B., Glatz J. P., Madic C., Malmbeck R., Modolo G. (2005) Separation and Purification Technology 45, 157-162

9. Modolo G., Wilden A., Geist A., Magnusson D., Malmbeck R. (2012). Radiochim. Acta 100, 715-725.

10. Ossola A., Macerata E., Tinonin D. A., Faroldi F., Giola M., Mariani M., Casnati A. (2015). Radiat. Phys. Chem.

11. Macerata E., Ossola A., Giola M., Faroldi F., Tinonin D. A. Actinide-lanthatide co-extraction by rigidified diglycolamides. Solvent Extraction and Ion Exchange. Vol. 36, Iss 1 (https://doi.org/10.1080/0 7366299.2017.1415670)

12. Lavrov G., Ustynyuk N., Gloriozov I., Ustynyuk Yu., Alyapyshev M., Tkachenko L., Babain V. (2017). A novel selective N-heterocyclic ligands for extraction separation of actinides and lanthanides. Abstracts of $9^{\text {th }}$ International Conference on Nuclear and Radiochemistry. NRC9. P.71.

13. Huittinen N., Scheinost A. C., Wilden A., Arinicheva Y. (2017). $\mathrm{Cm}^{3+}$ incorporation in $\mathrm{La}_{1-x} \mathrm{Gd}_{x} \mathrm{PO}_{4}$ monazites: a TRLFS and XAFS study. Abstracts of $9^{\text {th }}$ International Conference on Nuclear and Radiochemistry. NRC9. P.140.

14. Ohta H., Ogataa T., S. Van Winckelb, Papaioannoub D., Rondinella V. V. (2015). Evaluation of Minor Actinide Transmutation Performance in Fast Reactor Metal Fuel Irradiated up to 6.0 at.\% Burnup. Nuclear Science NEA/NSC/R 2.

\section{Современные методы радиохимической переработки отработанного ядерного топлива}

\section{Мальцева Т. В., Шишута А.Н., Лукашин С. А.}

Государственное предприятие «Государственный научно-технический центр по ядерной и радиационной безопасности», Киев, Украина

Статья посвящена истории развития и современному состоянию технологических и научных достижений в радиохимической переработке отработанного ядерного топлива энергетических реакторов с водяным охлаждением. Относительно отработанного ядерного топлива (ОЯТ) энергетических реакторов атомных электростанций долгосрочная энергетическая безопасность предполагает принятие варианта его радиохимической обработки, кондиционирования и рециркуляции. Переработка ОЯТ необходима для реализации замкнутого топливного цикла и повторного использования продуктов регенерации в качестве топлива энергетических реакторов. Основой современных технологических схем переработки отработанного ядерного топлива является процесс «Рurex», разработанный в 60-х годах в США. Классический подход к использованию нуклидов урана и плутония, содержащихся в отработавшем ядерном топливе, заключается в отделении их от про дуктов деления, повторном обогащении регенерированного урана и использовании плутония для производства топлива со смешанными оксидами с обедненным ураном. Современные перерабатывающие заводы способны справляться с топливом с дальнейшим повышением основных характеристик топлива без существенных изменений в первоначальном проекте. Чтобы закрыть топливный цикл, необходимо добавить следующие технологические этапы: (1) удаление высокорадиоактивных и долгоживущих компонентов и второстепенных актинидов; (2) возврат актинидов в технологический цикл; (3) безопасная утилизация неиспользованных компонентов. Каждое из этих направлений явля ется предметом современных исследований. Было разработано не сколько новых перспективных многоступенчатых гидрометаллургических процессов, основанных на совместной экстракции трехвалентных лантаноидов и минорных актинидов с последующим их разделением. Разработан ряд перспективных материалов, которые могут стать матрицей для иммобилизации высокоактивных компонентов радиоактивных отходов. Для улучшения совместимости обработки топлива с окружающей средой разрабатываются неводные технологии, например, пирохимические методы переработки различных типов высокоактивных топлив на основе металлов, оксидов, карбидов или нитридов. Исследуемой важной научно-технической задачей является трансмутация актинидов. Результаты международных крупномасштабных экспериментов по разделению и трансмутации топлива с различными малыми актинидами и долгоживущими продуктами деления подтверждают реальную возможность и целесообразность закрытия ядерного топливного цикла.

Ключевые слова: отработанное топливо, переработка, уран, плутоний, актиноиды, трансмутация.

\section{Modern Methods of Radiochemical Reprocessing of Spent Nuclear Fuel}

\section{Maltseva T., Shyshuta A., Lukashyn S.}

State Enterprise "State Scientific and Technical Center for Nuclear and Radiation Safety" Kyiv, Ukraine

The paper is devoted to the history of development and the current state of technological and scientific advances in radiochemical reprocessing of spent nuclear fuel from water-cooled power reactors. Regarding spent nuclear fuel (SNF) of NPP power reactors, long-term energy security involves adopting a version of its radiochemical treatment, conditioning and recirculation. Recycling SNF is required for the implementation of a closed fuel cycle and the re-use of regeneration products as energy reactor fuels. The basis of modern technological schemes for the reprocessing of the spent nuclear fuel is the "Purex" process, developed since the 60s in the USA The classic approach to the use of $U$ and Pu nuclides contained in spent nuclear fuel is to separate them from fission products, re-enrich regenerated uranium and use plutonium for the production of mixed-oxide (MOX) fuel with depleted uranium. The modern reprocessing plants are able to deal with fuel with further increase of its main characteristics without significant changes in the initial project. In order to close the fuel cycle, it is needed to add the following technological steps: (1) removal of high-level and long-lived components and minor actinides; (2) return of actinides to the technological cycle; (3) safe disposal of unused components. Each of these areas is under investigation now. Several new promising multi-cycle hydrometallurgical processes based on the joint extraction of trivalent lanthanides and minor actinides with their subsequent separation have been developed. A number of promising materials is suggested to be potential matrices for the immobilization of high-level components of radioactive wastes. To improve the compatibility of fuel processing with the environment, non-aqueous technologies are being developed, for instance, pyro-chemical methods for the reprocessing of various types of highly active fuels based on metals, oxides, carbides, or nitrides. An important scientific and technological task under investigation is transmutation of actinides. The results of international large-scale experiments on the partitioning and transmutation of fuel with various minor actinides and long-lived fission products confirm the real possibility and expediency of closing the nuclear fuel cycle.

Keywords: spent fuel, reprocessing, uranium, plutonium, actinides, transmutation.

Отримано 19.10.2018 